\title{
Dual-task functional exercises as an effective way to improve dynamic balance in persons with intellectual disability - continuation of the project
}

\section{Dwuzadaniowe ćwiczenia funkcjonalne jako efektywny sposób poprawy równowagi dynamicznej osób z niepetnosprawnością intelektualną - kontynuacja projektu}

\author{
Edyta Mikołajczyk ${ }^{1}$, Agnieszka Jankowicz-Szymańska² \\ ${ }^{1}$ Department of Physiotherapy, University of Physical Education, Krakow, Poland \\ Head of the Department: Prof. UPE Marek Pieniążek PhD \\ 2Institute of Health Sciences, State Higher Vocational School, Tarnow, Poland \\ Head of the Institute: Mariusz Pociecha PhD
}

Medical Studies/Studia Medyczne 2017; 33 (2): 102-109

DOI: https://doi.org/10.5114/ms.2017.68703

Key words: intellectual disability, dual task exercises, dynamic balance.

Słowa kluczowe: niepełnosprawność intelektualna, ćwiczenia dwuzadaniowe, równowaga dynamiczna.

\begin{abstract}
Introduction: Balance disorders are common in people with intellectual disability (ID).

Aim of the research: The continuation of the project is aimed at finding out whether extension of the unstable surface dualtask functional exercises programme by another 12 weeks affects the level of dynamic balance in adolescents with ID and what those changes are like after the 8-week summer holidays.

Material and methods: A total of 17 adolescents with ID aged 14-16 years (E) performed functional exercises for another 12 weeks on unstable surfaces, and a group of 17 individuals with ID were the controls. Dynamic balance was assessed three times: after the first stage of the programme (test 2), after another 12 weeks (test 3), after the 8-week holiday (test 4). ALFA AC An International East stabilometric platform was used for measurements.

Results: No statistical differences were discovered in group E, in dynamic balance assessment between test 2 and 3; however, the mean scores in group E, in test 3 , were slightly better than in test 2 , and notably better than in group C. No significant differences between test 3 and 4 were found in group $\mathrm{E}$ either.

Conclusions: Extension of the intervention program helped to maintain improved dynamic balance. Discontinuation of the program for the period of 8 weeks resulted in decreased level of balance; however, it was still higher than at the beginning of the project. Dual-task functional exercises based on activities of daily living (ADLs) and stimulation of righting reactions may enhance dynamic balance in individuals with ID, but it should be constantly stimulated.
\end{abstract}

\section{Streszczenie}

Wprowadzenie: Zaburzenia równowagi są powszechne u osób z niepełnosprawnością intelektualną (ID).

Cel pracy: Celem kontynuowanych badań jest sprawdzenie, czy wydłużenie programu dwuzadaniowych ćwiczeń o charakterze funkcjonalnym z wykorzystaniem niestabilnego podłoża o kolejne 12 tygodni wpłynie na zmianę poziomu równowagi dynamicznej młodzieży z ID, a także jak będą kształtować się te zmiany po zaprzestaniu ćwiczeń po 8-tygodniowym okresie wakacji.

Materiał i metody: Siedemnastu uczestników z ID w wieku 14-16 lat przez kolejne 12 tygodni wykonywało ćwiczenia funkcjonalne w warunkach niestabilnego podłoża (grupa E), a 17 osób z ID stanowiło kontrolę (C). Równowagę dynamiczną oceniono trzykrotnie: po pierwszym etapie ćwiczeń (badanie 2.), po kolejnych 12 tygodniach (badanie 3.) i po 8-tygodniowym okresie wakacji (badanie 4.). Wykorzystano platformę stabilometryczną ALFA AC International East.

Wyniki: Nie stwierdzono statystycznie istotnych różnic w grupie E pod względem równowagi dynamicznej pomiędzy badaniem 2. a badaniem 3. Jednak średnie wartości wszystkich parametrów w grupie E w badaniu 3. były nieznacznie lepsze niż w badaniu 2. i istotnie lepsze niż w grupie C. Nie wykazano istotnych statystycznie różnic w grupie E pomiędzy badaniem 3. a badaniem 4 .

Wnioski: Wydłużenie udziału w programie pozwoliło utrwalić równowagę dynamiczną. Przerwanie ćwiczeń na okres 8 tygodni spowodowało spadek poziomu równowagi, chociaż wyniki wciąż były lepsze niż na początku projektu. Dwuzadaniowe ćwiczenia oparte na aktywnościach dnia codziennego połączone ze stymulacją reakcji równoważnych mogą poprawić równowagę dynamiczną osób z ID, ale powinna ona być wciąż stymulowana. 


\section{Introduction}

The process of rehabilitating persons with intellectual disability (ID) should be strongly oriented towards solving their motor and functional problems, in order to help them achieve the best possible economic and social independence. The research to date has shown that children and adolescents with ID have numerous disturbances concerning both cognitive and motor functioning $[1,2]$. They are less active than their healthy peers [3, 4], prone to overweight and obesity $[5,6]$, and mostly lead a sedentary way of life [7, 8]. Balance control deficits observed in adolescents with ID, as compared to their healthy schoolmates [9], difficulties with the ability to concentrate on two or more things at a time [10], and problems with planning and organising movements [11] may increase the risk of accidental falls [12] and limit their independence in activities of daily living (ADLs) [13]. The study of Chiviacowsky et al. [14] proved that external verbal instructions, accompanying the task performance, supported its effective accomplishment and not only helped adolescents with ID to learn basic motor abilities but also positively influenced their social interactions.

The sense of balance in individuals with ID may be improved in many different ways [7, 15-18], but enhancement of their independence should always be of overriding importance. Most of the ADLs, which require body control and spatial orientation, are based on doing two or more things at the same time [19]. That was the reason why the authors of this study prepared batteries of dual-task functional exercises incorporating ADLs, performed with simultaneous stimulation of balance [20, 21]. Adolescents with ID participated in the 12-week intervention programme willingly. After that time, all their dynamic balance parameters on the platform (path length, test duration, and reaction time) improved greatly and were significantly better than in the controls [20]. Participants fully accepted the intervention programme, and it also received a sympathetic response from their parents and physiotherapists.

Enhanced balance parameters and participants' guardians' opinions on increased ADL performance made the authors of the project continue batteries of intervention exercises for another 12 weeks.

\section{Aim of the research}

The purpose of another study was to find out whether the extension of the dual-task functional exercises intervention programme on unstable surfaces by another 12 weeks would alter dynamic balance in adolescents with ID, how it would change, and how long the above would last after the end of the programme.

\section{Material and methods}

The study was a continuation of the project originated in January 2013 and conducted in the Group of Special Education Schools in Krakow. The school authorities were approached for their consent to continue the project, and written informed consent of the participants' legal guardians' was also obtained. The approval of the Ethical Committee of the Regional Medical Association in Krakow had been obtained prior to the study (no. 18/KBL/OIL/2012). The study was registered in the Australian New Zealand Clinical Trials Registry (ANZCTR). Registration number: ACTRN12616001235493.

This project involved adolescents with moderate intellectual disability, of aetiology other than genetic syndromes, who ambulated without orthopaedic devices. The exclusion criteria were major physical disabilities, genetic syndromes, hyperactivity, and an inability to follow instructions. According to the inclusion and exclusion criteria, 34 participants aged $14-16$ years (15.06 $\pm 0.9)$ were randomly assigned to the experimental (E) and the control group (C) at the beginning of the project (January 2013) through a simple randomisation procedure. A total of 34 adolescents continued participation in a subsequent stage of the project from the beginning of April to September 2013. At the beginning of the project, participants' average body weight equalled $67 \pm 16.2 \mathrm{~kg}$ and their height was 159.4 $\pm 12.7 \mathrm{~cm}$. All participants (from the experimental and control group) attended the same obligatory physical education (PE) classes in school two times per week. The physical education programme encompassed general body exercises and music therapy (spontaneous body movement developing different muscle groups inspired by music).

\section{Intervention programme}

Adolescents from the experimental group (E) additionally continued the dual-task intervention programme for another 12 weeks, taking part in 45-minute physical activities three times per week. They worked individually with the same therapists as before. The programme comprised exercises in which participants performed functional tasks consisting of ADLs on unstable surfaces (Swiss balls, stability trainers, and soft mattresses) (Table 1). All exercises followed a therapist's verbal instructions about focusing on the task accomplishment, the direction and target of the movement, and proper postural control. The therapist encouraged participants to perform exercises and praised them for their accuracy.

\section{Balance measurements}

Dynamic balance assessment was conducted in all participants after another 12 weeks of the interven- 
Table 1. Types of exercises performed by the experimental group

\begin{tabular}{|c|c|c|}
\hline \multicolumn{2}{|c|}{ Initial position } & \multirow{2}{*}{$\begin{array}{l}\text { Exercise description } \\
\text { Maintaining balance and lifting and lowering of the lower } \\
\text { extremity alternately }\end{array}$} \\
\hline 1 & Standing on two stability trainers & \\
\hline 2 & $\begin{array}{l}\text { Sitting on the Swiss ball at the table on } \\
\text { which there is a glass }\end{array}$ & $\begin{array}{l}\text { Maintaining balanced sitting position, with alternate reaching for } \\
\text { the glass and moving it towards the mouth, and putting it back on } \\
\text { the table as requested by the therapist. }\end{array}$ \\
\hline 3 & $\begin{array}{l}\text { Supported kneeling on two stability } \\
\text { trainers }\end{array}$ & $\begin{array}{l}\text { Alternate reaching with the upper extremity for an object held by } \\
\text { the therapist in his/her hand, or placed on the shelf at the height } \\
\text { of the participant's eyes }\end{array}$ \\
\hline 4 & $\begin{array}{l}\text { Standing position. Ten stability trainers } \\
\text { placed on the floor } 40 \mathrm{~cm} \text { apart; a table, } \\
\text { standing at the far end of the hall, with } \\
\text { a book on it }\end{array}$ & $\begin{array}{l}\text { Stepping on stability trainers towards the table to take the book } \\
\text { and return it to the therapist }\end{array}$ \\
\hline 5 & Sitting on the Swiss ball & $\begin{array}{l}\text { Balancing the body while sitting on the ball with alternate lifting of } \\
\text { the lower extremities and putting on and taking off footwear }\end{array}$ \\
\hline 6 & $\begin{array}{l}\text { Sitting on the Swiss ball placed in front of } \\
\text { shelves with different objects (e.g. books } \\
\text { or toys) }\end{array}$ & $\begin{array}{l}\text { Balancing the body while sitting on the ball, transition to the } \\
\text { standing position and reaching for an object, and returning to the } \\
\text { sitting position; transition to the standing position and putting the } \\
\text { object as requested by the therapist }\end{array}$ \\
\hline 7 & $\begin{array}{l}\text { Cross-legged sitting on the stability } \\
\text { trainer opposite the therapist sitting on } \\
\text { the floor }\end{array}$ & $\begin{array}{l}\text { Maintaining balanced sitting position, forward bend with reaching } \\
\text { the therapist's palm and returning to the initial position }\end{array}$ \\
\hline 8 & $\begin{array}{l}\text { Back lying next to the ball (or book, toy); } \\
\text { legs bent and feet on the stability trainer }\end{array}$ & $\begin{array}{l}\text { Maintaining balance and twisting the trunk to the sides and } \\
\text { moving the ball from the left to the right }\end{array}$ \\
\hline 9 & $\begin{array}{l}\text { Four elastic tapes fixed across the hall } \\
\text { at the alternate height of participants' } \\
\text { knees and arms, approximately one metre } \\
\text { apart }\end{array}$ & $\begin{array}{l}\text { Walking to the other side of the hall on soft mattresses and } \\
\text { stepping over low and going under high tapes }\end{array}$ \\
\hline 10 & Standing on two stability trainers & $\begin{array}{l}\text { Maintaining balance and leaning the body in different directions to } \\
\text { reach the ball held by the therapist }\end{array}$ \\
\hline 11 & $\begin{array}{l}\text { Standing in front of stability trainers } \\
\text { placed on the floor }\end{array}$ & Side stepping on stability trainers to the other end of the hall \\
\hline
\end{tabular}

tion programme (test 3) and 8 weeks after the end of the project (test 4) by the same physiotherapist, who was blinded to the group allocation. All adolescents did not take part in any organised forms of physical activity during the period of 8 weeks (summer holidays). Dynamic balance assessment was carried out on the stabilometric platform ALFA AC International East (distributed by P.H.U. Technomex, Poland). The same measurement conditions were maintained for all participants. Because the protocol for the first assessment (test 1) included software with the foot positioning on the platform for each participant in the normal relaxed standing position with their upper extremities hanging loosely by their sides, each consecutive measurement was conducted in the same position. Thanks to the above, it was possible to compare the results of subsequent measurements (test 2,3 , and $4)$. The same test parameters were set for all participants, i.e. the degree of difficulty - easy, the test duration time - $30 \mathrm{~s}$; and the number of repetitions - three, out of which the mean values were generated for the report. The centre of gravity (COG) was highly visible for the participant as a big green dot in the middle of the monitor (it corresponded to the centre of the platform). Participants could also see two lines dividing the monitor into four quarters, which corresponded to the quarters of the balance platform. The quarters of the platform were referred to in the platform software as: right-front: R-F, left-front: L-F, left-back: L-B, and right-back: R-B. The dynamic test consisted of performing the task mentioned below in a given time. On the monitor, yellow dots appeared one by one, which correlated with different areas of the base of support. The positions of the dots were pre-programmed depending on the test difficulty. Participants were asked to reach the dots by balancing their trunk and pelvis, and flexing their lower extremities towards the dot appearing on the monitor, but without lifting their feet off the platform. A required postural sway for healthy man towards the surface of the platform (normative 
data included in the platform software) in order to travel to the dots in the R-F and L-F quarters equalled $2.66^{\circ}(\mathrm{C} 1)$ and in the R-B and L-B it was $1.33^{\circ}(\mathrm{C} 3)$ and $1.99^{\circ}(\mathrm{C} 2)$, respectively (Figure 1). Participants heard a signal each time their COG reached the appropriate dot. Consecutive dots appeared on the monitor once the previous one had been found. The test was accomplished when all dots were reached.

The participants' assessment protocol, made after the test, included their path length $(\mathrm{cm})$, i.e. the entire path covered by the participant's centre of pressure (COP) within the time of the test and the time (in seconds) needed by the participant to reach all dots, and the times of reaching the dots in separate quarters of the platform.

\section{Statistical analysis}

The results collated were analysed using the arithmetic mean, the median, the minimum and maximum value, and the standard deviation. The inter- and intra-group differences were determined by means of One-way ANOVA and Factorial ANOVA, and post hoc Tukey test. The level of significance was accepted at $\alpha=0.05$. The analysis of the data collated was performed using Statistica v10 software.

\section{Results}

Table 2 shows participants' basic somatic traits observed after the first 12 weeks of the intervention programme (test 2), after another 12 weeks of performing exercises (test 3), and after 8 weeks of summer holidays, which followed the project (test 4 ). No differences of statistical significance in body height, weight, and body mass index (BMI) between the experimental group (E) and the controls (C) in tests 2, 3, and 4 was disclosed.

Table 3 shows dynamic balance parameters in the experimental group (E) and in the controls (C) after an-

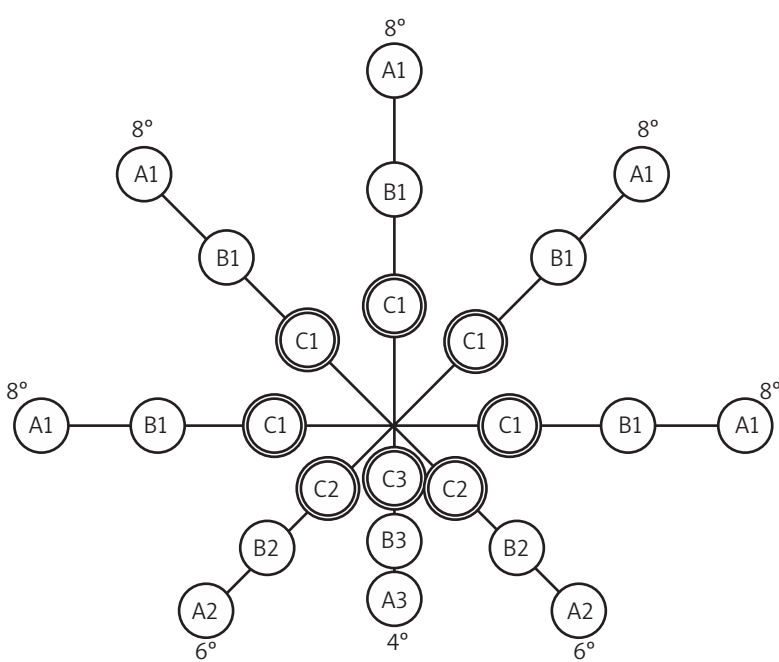

Figure 1. Target distribution in a dynamic test (C1, C2, C3 - easy test)

other 12 weeks of the intervention programme (test 3) and after 8 weeks from the end of the project (test 4).

Differences of statistical significance were disclosed in test 2 in all variables under analysis between the experimental group (E) and the controls (C), $p<0.05$ (Table 4).

The values referring to the path length, the relation of the path length to the minimum path, the time needed to accomplish the task, and the time needed to reach the dots in given quarters of the platform were significantly lower in the experimental group (E) than in the controls (C) (Table 4). The comparison of the results of test 2 and 3 did not reveal statistically significant differences of the variables under analysis in the experimental group (E) and in the controls (C). However, the mean value analysis might imply a tendency towards improving dynamic balance in group E. In test 3, the path length, the relation of the path length towards the minimum path,

Table 2. Inter-group comparison of the somatic traits results in the experimental (E) and control (C) group, one-way ANOVA, $\alpha=0.05$

\begin{tabular}{|c|c|c|c|c|c|c|c|c|c|c|c|c|}
\hline \multirow{2}{*}{$\begin{array}{l}\text { Term of } \\
\text { the study }\end{array}$} & \multicolumn{5}{|c|}{ Experimental group } & \multirow[t]{2}{*}{ Variable } & \multicolumn{5}{|c|}{ Control group } & \multirow{2}{*}{$\frac{\mathrm{E} \& \mathrm{C}}{P \text {-value }}$} \\
\hline & Mean & Median & Min. & Max. & SD & & Mean & Median & Min. & Max. & SD & \\
\hline Test 2 & 164.00 & 165.00 & 150.00 & 174.00 & 7.93 & \multirow{3}{*}{$\begin{array}{l}\text { Body } \\
\text { height } \\
{[\mathrm{cm}]}\end{array}$} & 164.00 & 166.00 & 145.00 & 180.00 & 8.68 & 0.99 \\
\hline Test 3 & 164.87 & 166.00 & 151.00 & 175.00 & 7.81 & & 165.00 & 167.00 & 148.00 & 181.00 & 8.28 & 0.96 \\
\hline Test 4 & 166.20 & 167.00 & 153.00 & 176.00 & 7.52 & & 166.21 & 168.00 & 150.00 & 182.00 & 8.00 & 0.93 \\
\hline Test 2 & 64.97 & 63.00 & 50.00 & 91.00 & 13.61 & \multirow{3}{*}{$\begin{array}{c}\text { Body } \\
\text { weight } \\
{[\mathrm{kg}]}\end{array}$} & 66.46 & 68.50 & 46.00 & 89.80 & 12.00 & 0.75 \\
\hline Test 3 & 63.73 & 62.00 & 50.00 & 87.00 & 11.73 & & 66.43 & 68.00 & 49.00 & 88.00 & 10.99 & 0.54 \\
\hline Test 4 & 63.93 & 63.00 & 50.00 & 87.00 & 11.28 & & 67.07 & 68.00 & 52.00 & 88.00 & 10.64 & 0.47 \\
\hline Test 2 & 24.34 & 21.70 & 18.40 & 34.70 & 5.81 & \multirow{3}{*}{$\begin{array}{c}\mathrm{BMI} \\
{\left[\mathrm{kg} / \mathrm{m}^{2}\right]}\end{array}$} & 24.50 & 25.30 & 18.38 & 27.84 & 3.01 & 0.33 \\
\hline Test 3 & 23.58 & 21.70 & 18.30 & 32.80 & 4.91 & & 24.33 & 25.04 & 19.06 & 27.16 & 2.58 & 0.26 \\
\hline Test 4 & 23.12 & 21.40 & 18.40 & 31.00 & 4.16 & & 24.19 & 24.95 & 19.42 & 26.96 & 2.40 & 0.25 \\
\hline
\end{tabular}


Table 3. Dynamic balance results in the experimental (E) and control (C) group

\begin{tabular}{|c|c|c|c|c|c|c|c|c|c|c|c|}
\hline \multirow{2}{*}{$\begin{array}{l}\text { Term of } \\
\text { the study }\end{array}$} & \multicolumn{5}{|c|}{ Experimental group } & \multirow[t]{2}{*}{ Variable } & \multicolumn{5}{|c|}{ Control group } \\
\hline & Mean & Median & Min. & Max. & SD & & Mean & Median & Min. & Max. & SD \\
\hline Test 2 & 177.77 & 168.06 & 117.58 & 328.04 & 55.40 & \multirow{3}{*}{$\begin{array}{l}\text { Path } \\
\text { length }\end{array}$} & 263.25 & 228.54 & 172.74 & 455.2 & 89.47 \\
\hline Test 3 & 172.99 & 156.76 & 117.58 & 326.14 & 51.43 & & 267.36 & 245.10 & 172.55 & 456.9 & 80.02 \\
\hline Test 4 & 188.85 & 177.21 & 140.93 & 327.01 & 46.57 & & 263.18 & 235.79 & 174.20 & 485.4 & 96.72 \\
\hline Test 2 & 388.64 & 346.00 & 248.00 & 769.00 & 131.16 & \multirow{3}{*}{$\begin{array}{c}\text { Path/min } \\
\text { path } \\
\text { length }\end{array}$} & 613.19 & 592.33 & 358.00 & 1067.0 & 191.51 \\
\hline Test 3 & 374.24 & 342.00 & 248.00 & 741.49 & 112.50 & & 594.47 & 549.50 & 349.00 & 1068.0 & 182.52 \\
\hline Test 4 & 408.96 & 385.50 & 319.00 & 776.16 & 112.86 & & 579.55 & 513.66 & 393.00 & 1036.0 & 199.55 \\
\hline Test 2 & 26.96 & 24.81 & 20.10 & 62.57 & 9.50 & \multirow{3}{*}{$\begin{array}{l}\text { Total } \\
\text { time }\end{array}$} & 50.37 & 50.57 & 29.32 & 66.87 & 11.60 \\
\hline Test 3 & 24.70 & 23.44 & 20.61 & 34.15 & 3.38 & & 49.31 & 51.42 & 32.51 & 63.41 & 11.08 \\
\hline Test 4 & 25.05 & 24.81 & 21.20 & 35.16 & 3.92 & & 45.52 & 42.21 & 30.11 & 62.60 & 10.68 \\
\hline Test 2 & 2.18 & 1.73 & 0.08 & 8.41 & 1.75 & \multirow{3}{*}{$\begin{array}{l}\text { Time of } \\
\text { reaching } \\
\text { R-F } \\
\text { direction }\end{array}$} & 5.74 & 4.70 & 3.17 & 13.41 & 2.65 \\
\hline Test 3 & 1.81 & 1.67 & 1.42 & 3.25 & 0.43 & & 5.10 & 4.32 & 2.30 & 12.31 & 2.69 \\
\hline Test 4 & 1.97 & 1.99 & 1.38 & 3.11 & 0.45 & & 4.30 & 3.25 & 2.30 & 8.56 & 2.24 \\
\hline Test 2 & 2.41 & 1.85 & 1.33 & 8.50 & 2.13 & \multirow{3}{*}{$\begin{array}{l}\text { Time of } \\
\text { reaching } \\
\text { L-F } \\
\text { direction }\end{array}$} & 4.51 & 3.70 & 2.80 & 10.50 & 1.97 \\
\hline Test 3 & 1.82 & 1.83 & 1.18 & 2.36 & 0.28 & & 3.64 & 3.16 & 1.92 & 8.21 & 1.69 \\
\hline Test 4 & 1.94 & 1.82 & 1.18 & 3.28 & 0.56 & & 3.46 & 3.32 & 1.50 & 8.62 & 1.77 \\
\hline Test 2 & 2.18 & 1.92 & 1.52 & 4.22 & 0.69 & \multirow{3}{*}{$\begin{array}{l}\text { Time of } \\
\text { reaching } \\
\text { L-B } \\
\text { direction }\end{array}$} & 4.23 & 4.31 & 1.34 & 8.01 & 2.02 \\
\hline Test 3 & 2.02 & 1.87 & 1.27 & 4.44 & 0.76 & & 4.34 & 3.69 & 2.11 & 8.31 & 1.78 \\
\hline Test 4 & 2.10 & 1.91 & 1.41 & 4.44 & 0.79 & & 3.30 & 2.56 & 1.34 & 7.07 & 1.77 \\
\hline Test 2 & 2.24 & 1.98 & 0.85 & 6.83 & 1.31 & \multirow{3}{*}{$\begin{array}{c}\text { Time of } \\
\text { reaching } \\
R-B \\
\text { direction }\end{array}$} & 5.50 & 5.50 & 2.22 & 8.67 & 2.10 \\
\hline Test 3 & 1.82 & 1.70 & 1.16 & 2.43 & 0.41 & & 4.25 & 3.93 & 2.13 & 7.22 & 1.51 \\
\hline Test 4 & 1.88 & 1.83 & 1.14 & 3.01 & 0.46 & & 4.00 & 3.76 & 1.11 & 7.98 & 1.80 \\
\hline
\end{tabular}

$S D$ - standard deviation, $R-F$ - right-front, $L-F-$ left-front, $L-B$ - left-back, $R$ - $B$ - right-back.

the general time, and the time of reaching the dots in separate quarters of the platform were significantly shorter $(p<0.05)$ in the experimental group (E) than in the controls $(C)$.

The comparison of the results of tests 3 and 4 again did not reveal differences of statistical significance $(p>0.05)$ in all variables under analysis in the experimental group (E) and in the controls (C) (Table 4). While analysing the mean values of separate variables in test 4 , it was revealed that they maintained a similar level as in tests 3 and 2. Test 4 disclosed significantly shorter time of accomplishing the test and shorter times of reaching the dots in the R-F and R-B quarters of the platform in the experimental group (E) than in the controls $(\mathrm{C})$.

There were no statistically significant differences between groups $\mathrm{E}$ and $\mathrm{C}$ for the path length and the ratio of the path length to the minimum path, and the time of reaching the dots in the L-F and L-B quarters of the platform. Table 4 includes detailed results of group by time interaction.

\section{Discussion}

The 12-week dual-task functional exercises intervention programme described in the previous paper [20] exerted a considerable improvement of dynamic balance in adolescents with ID. The extension of the programme by another 12 weeks only slightly improved the results achieved earlier. However, the mean value analysis showed a slightly higher level of dynamic balance despite the fact that no statistical significance was revealed. It seemed to be important that after the 8-week holiday (test 4), the level of variables were similar to those achieved in tests 3 and 2 . It should also be mentioned that after the first 12 weeks, an extremely distinct improvement of the results of all parameters describing the dynamic balance test was noticed in the experimental group. The path length shortened by $65 \%$ in relation to its initial value, the time needed to accomplish the task diminished by $59 \%$, and adequately shorter times of reaching the dots in separate quarters of the balance platform were 
Table 4. Intra- and inter-group comparison of the dynamic balance variables (factorial ANOVA and post hoc Tukey test, $\alpha=0.05)$

\begin{tabular}{|c|c|c|c|c|c|c|c|}
\hline \multirow{2}{*}{$\begin{array}{l}\text { Compared } \\
\text { groups }\end{array}$} & \multicolumn{7}{|c|}{ Variable ( $p$-value) } \\
\hline & $\begin{array}{l}\text { Path } \\
\text { length }\end{array}$ & $\begin{array}{l}\text { Path/min } \\
\text { path length }\end{array}$ & $\begin{array}{l}\text { Total } \\
\text { time }\end{array}$ & $\begin{array}{l}\text { Time of } \\
\text { reaching R-F } \\
\text { direction }\end{array}$ & $\begin{array}{l}\text { Time of } \\
\text { reaching L-F } \\
\text { direction }\end{array}$ & $\begin{array}{l}\text { Time of } \\
\text { reaching L-B } \\
\text { direction }\end{array}$ & $\begin{array}{c}\text { Time } \\
\text { of reaching } \\
\text { R-B direction }\end{array}$ \\
\hline E2 \& E3 & 0.99 & 0.99 & 0.97 & 0.99 & 0.88 & 0.99 & 0.95 \\
\hline E3 \& E4 & 0.98 & 0.98 & 0.99 & 0.99 & 0.99 & 0.99 & 0.99 \\
\hline E2 \& E4 & 0.99 & 0.99 & 0.99 & 0.99 & 0.95 & 0.99 & 0.99 \\
\hline$C 2 \& C 3$ & 0.99 & 0.99 & 0.99 & 0.93 & 0.61 & 0.99 & 0.12 \\
\hline$C 3 \& C 4$ & 0.99 & 0.99 & 0.86 & 0.87 & 0.46 & 0.36 & 0.99 \\
\hline$C 2 \& C 4$ & 0.99 & 0.99 & 0.68 & 0.33 & 0.99 & 0.48 & 0.051 \\
\hline E2 \& C2 & $0.009^{*}$ & $0.001^{*}$ & $0.0001^{*}$ & $0.0001^{*}$ & $0.002^{*}$ & $0.0008^{*}$ & $0.0001^{\star}$ \\
\hline E2 \& C3 & $0.006^{*}$ & $0.004^{*}$ & $0.0001^{*}$ & $0.0006^{*}$ & $0.004^{*}$ & $0.0005^{*}$ & $0.0001^{\star}$ \\
\hline E2 \& C4 & $0.020^{\star}$ & $0.017^{\star}$ & $0.0001^{\star}$ & $0.043^{*}$ & $0.034^{\star}$ & $0.021^{*}$ & $0.001^{*}$ \\
\hline E3 \& C2 & $0.005^{*}$ & $0.0004^{\star}$ & $0.0001^{*}$ & $0.0001^{*}$ & $0.0001^{*}$ & $0.0003^{*}$ & $0.0001^{\star}$ \\
\hline E3 \& C3 & $0.003^{*}$ & $0.001^{*}$ & $0.0001^{*}$ & $0.0001^{*}$ & $0.015^{*}$ & $0.0002^{*}$ & $0.0001^{*}$ \\
\hline E3 \& C4 & $0.011^{*}$ & $0.008^{*}$ & $0.0001^{\star}$ & $0.009^{*}$ & 0.06 & 0.14 & $0.0001^{\star}$ \\
\hline E4 \& C2 & $0.041^{*}$ & $0.004^{\star}$ & $0.0001^{*}$ & $0.0001^{*}$ & $0.0002^{*}$ & $0.0006^{*}$ & $0.0001^{*}$ \\
\hline E4 \& C3 & $0.029^{\star}$ & $0.015^{*}$ & $0.0001^{*}$ & $0.0003^{*}$ & $0.034^{\star}$ & $0.0003^{*}$ & $0.0003^{*}$ \\
\hline E4 \& C4 & 0.069 & 0.051 & $0.0001^{*}$ & $0.021^{*}$ & 0.11 & 0.21 & $0.003^{*}$ \\
\hline
\end{tabular}

$E$-experimental group, $C$ - control group, $R$ - $F$ - right-front, $L-F$ - left-front, $L-B$ - left-back, $R$ - $B$ - right-back.

observed, i.e. by $47 \%$ R-F, $75 \%$ L-F, $45 \%$ L-B, and $56 \%$ $\mathrm{R}-\mathrm{B}$ [20]. On the other hand, the analysis of the mean values of the results could indicate a trend towards obtaining worse results after discontinuing systematic batteries of exercises.

The studies on the effect of dual-task functional exercises on motor and functional abilities of persons with ID have not been sufficiently documented so far, and the authors found it rather difficult to refer the results of their dynamic balance tests to other publications. The observations to date have shown unfavourable differences between individuals with Down's syndrome (DS) and their healthy peers in accomplishing dual tasks, seen in some time and space parameters of the gait. Since the accomplishment of dual tasks requires greater concentration, rehabilitation of individuals with cognitive disturbances should comprise both physical training and stimulation of focusing attention on the tasks being performed [22].

Improved static balance in participants with ID was achieved through multiple repetition of functional tasks (e.g. placing a book on a shelf), in which the therapist's additional verbal instructions stimulated the person performing the exercises to concentrate on the targeted movement of the extremity, its direction, and the body position on the unstable surface (Swiss ball, stability disc). A shorter COP path length in the eyes open and closed conditions and a de- creased surface area with the eyes closed test [21] were achieved after the first 12 weeks of the intervention programme. Continuation of the programme brought further shortening of the path length, both in the eyes-open and eyes-closed condition. The long-term facilitation effects were confirmed in the static balance assessment and after the 8-week summer holidays (test 4) [23]. Improved functional performance in children with severe ID and accompanying motor disturbances [24] was achieved through multiple repetitions of functional tasks based on the ADLs. The effectiveness of functional therapy oriented towards solving functional problems and improving motor abilities in children with cerebral palsy (CP) was also confirmed by Ketelaar's studies [25].

Maintaining balanced postural alignment while performing a motor task, which required complex motor abilities (e.g. reaching for a glass or a book, or putting on footwear) and standing on a stability disc or sitting on a Swiss ball at the same time required interactions between the visual, somatosensory, and vestibular systems [26]. Postural control rehabilitation in children and adolescents with balance deficits should include activities improving performance of static and dynamic balance tasks concerning the musculoskeletal and locomotor systems and sensory factors limiting the speed of processing information [13]. Performance of exercises on unstable surfaces, 
suggested in the intervention programme, required increased control of the foot and ankle joint movements, i.e. greater proprioceptive feedback from the foot and ankle joint proprioceptors [27]. Participants performed exercises barefooted, which additionally stimulated the mechanoreceptors of the foot (its sole side is one of the most important zones of proprioceptive sensory input entry) [28] and aroused proprioceptive information to the trunk and other postural muscles [29]. Functional tasks consisting of the ADLs required both the ability to concentrate on one or more things at a time, as well as balanced postural alignment [30] in which the anticipatory postural adjustment (APA) [31] played the key role. Research on children and adolescents with normal posture revealed that the APA could adjust to the changeable external conditions that affected stable postural alignment [31] and the APA patterns by a one-time training of functional activities developing righting reactions and the speed of reaction in healthy individuals [32]. According to the authors of the study, improved postural control revealed after a single intervention programme might also be reflected in individuals who require an increased sense of stability [32]. ShumwayCook et al. [33] found out that postural control mechanisms possessed adaptation and modification possibilities in children with CP. A significantly improved postural alignment and postural control were discovered in balance exercises on the platform, which was reflected by a smaller area covered by the COP and the time needed to stabilise postural alignment. The scores of participants with CP remained at the same level in the examination conducted 4 weeks after the termination of the project [33].

In our study, reaching the consecutive dots in a given area, which in the dynamic test appeared in the quarters of the platform, required participants to focus on the dots on the monitor and alternate concentric and eccentric engagement of the muscles of the lower extremities and the postural muscles, in order to control the sway in the right direction and regain a stable posture. The results of the dynamic test in the experimental group revealed increased postural stability and control expressed by a shorter time of reaching the points in the proximal-distal direction and a shortened stabilogram path. The results significantly improved after the first 12 weeks of the intervention programme, and after another 12 weeks they were even more lasting. On the other hand, the analysis of the results achieved after the 8-week holiday showed a tendency towards achieving worse balance parameters after discontinuing systematic exercises. Those observations could imply the need for constant stimulation of righting reactions in adolescents with ID. It seemed appropriate to engage parents in the rehabilitation process so it could continue throughout the time when there were no classes at school. Those suggestions were convergent with Ketelaar's et al. ob- servations [25], who emphasised a great role of the family in conducting functional therapies.

Increased feeling of the body - expressed by the positive results of the dynamic test on the balance platform, achieved due to multiple repetitions of the functional activity exercises on unstable surfaces may be reflected in emergency situations, e.g. while on a bus when its driver breaks in an emergency or when being pushed or jostled, when a quick motor reaction is needed to maintain postural alignment stable enough to prevent accidental falls.

This study has certain limitations, the main one being that the project was performed in a relatively small group of adolescents with ID, and its findings cannot be applied to the wider target population. Further studies should be extended by assessing functional performance of daily life skills and the quality of gait due to the fact that the proposed dual-task exercises programme consisted of exercises based on ADLs.

\section{Conclusions}

Extension of the intervention program helped to maintain improved dynamic balance. Discontinuation of the program for a period of 8 weeks resulted in decreased levels of balance; however, it was still higher than at the beginning of the project. Dual-task functional exercises based on activities of daily living (ADLs) and stimulation of righting reactions may enhance dynamic balance in individuals with ID, but it should be constantly stimulated.

\section{Acknowledgments}

We would like to thank all the participants and physiotherapists from the Group of Special Education Schools in Krakow, who took part in our project.

\section{Conflict of interest}

The authors declare no conflict of interest.

\section{References}

1. Golubovic S, Maksimovic J, Golubovic B, Glumbic N. Effects of exercise on physical fitness in children with intellectual disability. Res Dev Disabil 2012; 33: 608-14.

2. Wuang YP, Wang CC, Huang MH, Su CY. Profiles and cognitive predictors of motor functions among early school-age children with mild intellectual disabilities. J Intellect Disabil Res 2008; 52: 1048-60.

3. Kozub FM. Explaining physical activity in individuals with mental retardation: an exploratory study. Education and Training in Developmental Disabilities 2003; 38: 302-13.

4. Hinckson EA, Curtis A. Measuring physical activity in children and youth living with intellectual disabilities: a systematic review. Res Dev Disabil 2013; 34: 72-86.

5. Allerton LA, Welch V, Emerson E. Health inequalities experienced by children and young people with intel- 
lectual disabilities: a review of literature from the United Kingdom. J Intellect Disabil 2011; 15: 269-78.

6. Rimmer JH, Rowland JL, Yamaki K. Obesity and secondary conditions in adolescents with disabilities: addressing the needs of an underserved population. J Adolesc Health 2007; 41: 224-9.

7. Lotan M, Isakov E, Kessel S, Merrick J. Physical fitness and functional ability of children with intellectual disability: effects of a short-term daily treadmill intervention. Sci World J 2004; 4: 449-57.

8. Pitetti KH, Boneh S. Cardiovascular fitness as related to leg strength in adults with mental retardation. Med Sci Sports Exerc 1995; 27: 423-8.

9. Blomqvist S, Olsson J, Wallin L, Wester A, Rehn B. Adolescents with intellectual disability have reduced postural balance and muscle performance in trunk and lower limbs as compared to peers without intellectual disability. Res Dev Disabil 2013; 34: 198-206.

10. Oka K, Miura T. Allocation of attention and effect of practice on persons with and without mental retardation. Res Dev Disabil 2008; 29: 165-75.

11. Hartman E, Houwen S, Scherder E, Visscher C. On the relationship between motor performance and executive functioning in children with intellectual disabilities. J Intellect Disabil Res 2010; 54: 468-77.

12. Cox CR, Clemson L, Stancliffe RJ, Durvasula S, Sherringhton C. Incidence of and risk factors for falls among adults with an intellectual disability. J Intellect Disabil Res 2010, 54: 1045-57.

13. Westcott SL, Burtner PA. Postural control in children: implications for pediatric practice. Phys Occup Ther Pediatr 2004; 24: 5-55.

14. Chiviacowsky S, Wulf G, Avila LT. An external focus of attention enhances motor learning in children with intellectual disabilities. J Intellect Disabil Res 2013; 57: 627-34.

15. Yilmaz I, Ergu N, Konukman F, Agbuga B, Zorba E, Cimen Z. The effects of water exercises and swimming on physical fitness of children with mental retardation. J Hum Kinet 2009; 21: 105-11.

16. Giagazoglou P, Arabatzi F, Dipla K, Liga M, Kellis E. Effect of a hippotherapy intervention program on static balance and strength in adolescents with intellectual disabilities. Res Dev Disabil 2012; 33: 2265-70.

17. Tsimaras VK, Giamouridou GA, Kokaridas DG, Sidiropoulou MP, Patsiaouras AI. The effect of a traditional dance training program on dynamic balance of individuals with mental retardation. J Strength Cond Res 2012; 26: 192-8.

18. Fotiadou EG, Neofotistou KH, Sidiropoulou MP, Tsimaras VK, Mandroukas AK, Angelopoulou NA. The effect of a rhythmic gymnastics program on the dynamic balance ability of individuals with intellectual disability. J Strength Cond Res 2009; 23: 2102-6.

19. Silsupadol P, Siu K, Shumway-Cook A, Woollacott MH. Training of balance under single- and dual-task conditions in older adults with balance impairment. Phys Ther 2006; 86: 269-81.

20. Mikolajczyk E, Jankowicz-Szymanska A. The effect of dual-task functional exercises on postural balance in adolescents with intellectual disability - a preliminary report. Disabil Rehabil 2015; 37: 1484-9.

21. Mikolajczyk E, Jankowicz-Szymanska A. The effect of unstable-surface functional exercise on static balance in adolescents with intellectual disability - a preliminary report. Medical Studies/Studia Medyczne 2014; 30: 1-5.

22. Horvat M, Croce R, Tomporowski P, Barna MC. The influence of dual-task conditions on movement in young adults with and without Down syndrome. Res Dev Disabil 2013; 34: 3517-25.

23. Mikolajczyk E, Jankowicz-Szymanska A. Does extending the dual-task functional exercises workout improve postural balance in individuals with ID? Res Dev Disabil 2015; 38: 84-91.

24. van der Putten A, Vlaskamp C, Reynders K, Nakken H. Children with profound intellectual and multiple disabilities: the effects of functional movement activities. Clin Rehabil 2005; 19: 613-20.

25. Ketelaar M, Vermeer A, Hart H, van Petegem-van Beek E, Helders PJ. Effects of a functional therapy programme on motor abilities of children with cerebral palsy. Phys Ther 2001; 81: 1534-45.

26. Shumway-Cook A, Woollacott MH. Motor Control: Theory and practical applications. Lippincott/Williams \& Wilkins. Baltimore, Maryland, USA 2000.

27. Stillman BC. Making sense of proprioception: the meaning of proprioception, kinaesthesia and related terms. Physiotherapy 2002; 88: 667-46.

28. Shin SS, An DH. The effect of motor dual-task balance training on balance and gait of elderly women. J Phys Ther Sci 2014; 26: 359-61.

29. Roll R, Kavounoudias A, Roll JP. Cutaneous afferents from human plantar sole contribute to body posture awareness. Neuroreport 2002; 13: 1957-61.

30. Horst R. Motorisches Strategie training und PNF. Georg Thieme Verlag KG, Stuttgart 2005.

31. Girolami GL, Shiratori T, Aruin AS. Anticipatory postural adjustments in children with typical motor development. Exp Brain Res 2010; 25: 153-65.

32. Kanekar A, Aruin AS. Improvement of anticipatory postural adjustments for balance control: effect of single training session. J Electromyogr Kinesiol 2015; 25: 400-5.

33. Shumway-Cook A, Hutchinson S, Kartin D, Price R, Woollacott M. Effect of balance training on recovery of stability in children with cerebral palsy. Dev Med Child Neurol 2003; 45: 591-602.

\section{Address for correspondence:}

Edyta Mikołajczyk PhD

Department of Physiotherapy

University of Physical Education

Al. Jana Pawła II 78, 31-571 Krakow, Poland

Phone: +48126831167

E-mail: edytamiko@gmail.com 